\title{
Multipl Sklerozisin Immünpatogenezi Kısım 1: Her plak aynı mıdır?
}

\author{
Immüpatholegenesis of Multiple Sclerosis \\ Part 1: Are all the plaques the same?
}

\author{
Atay Vural ${ }^{1}$, Aslı Tuncer Kurne' ${ }^{1}$, Rana Karabudak ${ }^{1}$
}

Geçtiğimiz 10 yıl nörolojide nöroimmunolojik hastalıkların giderek ön plana çıktığı bir dönem olmuștur. Özellikle multipl sklerozis, nöromyelitis optika ve limbik ensefalitlerin immünpatogenezi hakkındaki bilgiler çok artmıș, söz konusu hastalıkların tanı ve tedavisiyle ilgili yeni tedaviler keșfedilmiștir. Nörolojik ve immün sistem gibi vücudun en karmașık iki sisteminin hatalı etkileșmesi sonucu olușan bu hastalıklar tüm nöroloji uzmanlarının meslek hayatları boyunca pek cok kez karșılașacağı hastalıklardır. Bu hastaların bilinçli bir sekilde takiplerinin yapılabilmesi için, nörologların hastalık immünpatogenezleri hakkında bilgi sahibi olmaları elzemdir. İki kısımdan olușan bu derlemede, nöroimmünolojik hastalıkların prototipi olan multipl sklerozisin immünpatogenezi anlatılarak, tıp öğrencilerinin, nöroloji asistan ve uzmanlarının nöroimmünoloji bilgilerinin arttırılması hedeflenmiștir. Bu ilk kısımda, multipl skleroz plaklarının histopatolojik özelliklerinden bahsedilerek, MR görüntülemede lezyon yükü cok fazla olan bir kișinin klinik durumu çok iyi olabilirken, neden daha az sayıda lezyonu olan birinin kliniğinin çok daha ağır olabildiği gibi sorulara yanıt aranacaktır.

Anahtar Sözcükler: Multipl Skleroz, Patogenez, İmmünoloji, Histoloji

Neuroimmunological disorders came to the forefront in neurology in the past decade. Especially, our knowledge on multiple sclerosis, neuromyelitis optica and limbic encephalitis have massively grown and important diagnostic and therapeutic advances have been made. These disorders arise from the faulty interaction of the two most complex systems of human body: neurological and immune systems. Neurologists will encounter these disorders many times in a life time and they will need an understanding of the immunopathogenesis in order to be able to treat such diseases. In this two-part review, we aim to increase knowledge of medical students, neurology residents and neurologists on neuroimmunology. We will try to do this by explaining immunopathogenesis of the prototypical disorder: multiple sclerosis. In this first part, we will describe the types and histopathological characteristics of multiple sclerosis plaques and try to answer the intriguing question of why some patients with excessive number of lesions are in good clinical condition, while the others with lower plaque load have severe disease.

Key words: Multiple Sclerosis, Pathogenesis, Immunology, Histology

\section{Plan:}

\section{Kısım I}

1. Giriş

2. Histopatolojik çalışmalar

2.1. İncelemede kullanılan yöntemler

2.2. Plak çeșitleri

2.3. Aktif plak paternleri

2.3.1 Dört patern hipotezi

2.3.2 Paternlerin evrimi hipotezi

2.3.3 İleri evrelerde plak paternleri

2.4. Gölge plaklar

2.5. Kortikal plaklar

\section{Kısım II}

3. Hastalığın doğuşu: DAE modelinden öğrenilenler

3.1. Modeller

3.2. İlk başta neler oluyor?

3.2.1 Birinci dalga ve immünsurveyans kavram

3.2.2 İkinci dalga: Lenfosit olimpiyatları ve kemokinler

3.3. İmmün hücrelerin kan-beyin bariyerinden geçişi

3.4. Relaps ve remisyonların üç silahşörü

4. Manyetik rezonans görüntülemenin öğrettikleri

4.1. Konvansiyonel MRG'nin öğrettikleri

4.2. Non-konvansiyonel MRG'nin öğrettikleri 
Günümüzde bir multipl skleroz (MS) hastasının takibinde en yararlı yöntem manyetik rezonans görüntülemedir (MRG). Elde edilen görüntülerde kontrast madde tutan lezyon olup olmadığına bakılır, önceki MRG'ye göre lezyon yükünde artış olup olmadığ1 incelenir ve sonuçta tedavi uygun şekilde düzenlenir. Ancak hastalığın nasıl başladığı, T1 kesitlerde halkaşeklinde kontrast tutan lezyonların nasıl oluştuğu, T2 ve fluid attenuated inversion recovery (FLAIR) kesitlerinde birbirine benzeyen diğer plakların gerçekten aynı olup olmadığı ve normal görünen beyaz cevherin (NGBC) ve korteksin de gerçekte hastalıklı olup olmadığı gibi önemli bilgiler hekim tarafindan bilinmez. Çünkü bu bilgiler konvansiyonel MRG görüntüleriyle elde edilemez. Son on yılda, geliştirilen yeni tekniklerle birlikte; gerek insanda, gerek hayvan modelleriyle yapılan çalışmalar sayesinde bu sorularin bir kismina cevap sağlayacak önemli bulgular elde edilmiştir. Bu çalışmaların üç ayağını insandaki otopsi/biyopsi materyallerinin histopatolojik incelemeleri, deneysel alerijk ensefalomiyelit (DAE) çalışmaları ve non-konvansiyonel MRG çalışmaları oluşturmaktadır.

$\mathrm{Bu}$ derleme ile, bütün bu alanlardaki önemli gelişmelerin bir araya getirilerek hastalıkla uğraşan uzmanların hastalığın başlangıcı, gelişimi ve ileri evrelerindeki mekanizmalar hakkinda bilgilerinin derinleştirmesi hedeflenmektedir.

\section{Histopatolojik çalıșmalar}

Multipl sklerozun - halen geçerliliğini koruyan - ilk histopatolojik tanımlamas1 1868 y1linda Jean-Martin Charcot tarafindan yapılmıştır. Bu tanıma göre MS, beyinde fokal inflamasyon ve demiyelinizasyon alanlariyla karakterize sert plaklardan oluşan bir hastalıktır. Gliozis ve görece akson korunumu da o dönemden bu yana iyi bilinen diğer özelliklerdir (1).

1990’larda Lucchinetti ve arkadaşları (2) tarafindan yapılan öncü çalışmalarda, üç farklı merkezin katılımıla bir otopsi/biyopsi koleksiyonu oluşturulmuş, hastalığın patogenezinin aydınlatılması ve farklı klinik özellik gösteren hastalarda farklı patogenezlerin rol oynayıp oynamadığının incelenmesi hedeflenmiştir. İkibin y1linda yayınlanan ve detaylı immünohistokimyasal (IHK) inceleme sonuçlarının sunulduğu çalışmayla, MRG ve rutin IHK kesitlerinde benzer görünen plakların, aslında dört farklı immunopatern gösterdiği gösterilmiştir (2). O tarihten beri Avustralya'daki otopsi vakaları üzerindeki çalışmalar; Hollanda Beyin Bankasinın ve İngiltere'deki MS beyin bankasının konu hakkındaki yayınları bilgi birikimini arttırmanın yanı sıra tartışmaların da alevlenerek devam etmesine sebep olmuştur.

\section{1 İncelemede kullanılan yöntemler}

Büyük hacmi ve çabuk nekroza gidebilmesi nedeniyle incelemesi oldukça zor olan insan beyni otopsi/biyopsi materyallerinin en etkili şekilde incelenebilmesi için son on yılda bazı standartlar getirilmiştir. Kullanılan boyaların çeșitliliğinin artması dıșında, baz1 merkezlerde beyin kesitlerine MRG yapilarak in vivo saptanmayan plakların da tespit edilmesi ve incelenmesi mümkün hale gelmiştir $(3,4)$.

İmmünohistokimya yapilacak kesitler bir kez belirlendikten sonra, ilk olarak parafine gömülü kesitler hemotoksilen-eosin (HE), miyelin boyası olarak luksol-fast mavisi (LFB) ve aksonlar için de gümüş boyalar ile boyanır. Dondurulmuş kesitler sindirilmiş miyelin parçacıkları için oil-red-O ile boyanir. Ayrica miyelin basic protein (MBP), myelin oligodendrocyte protein (MOG), myelin associated glycoprotein (MAG), proteolipid protein (PLP), 2'3'-cyclic nucleotide 3'phosphodiesterase (CNP), HNK-1 gibi diğer özgül miyelin ve oligodendrosit boyalar1; makrofajlar ve mikroglialar için MRP14, CD68 veya KiM1P; lenfositler için CD3, 4, 8 ve 20; dendritik hücreler için CD209; astrositler için glial fibrillary protein (GFP), kompleman ve immünglobulinler ve MHC-II boyaması da siklıkla kullanılan diğer immünohistokimyasal boyalardır $(2,5,6)$.
Aktif bir plak içerisindeki hasarlanmış myelin tabakası, makrofajlar tarafindan immünglobulinler, kompleman ve diğger doğal bağışıklık reseptörleriyle fagosite edilir ve takiben lizozomlar tarafindan yıkılır. Değişik büyüklükteki miyelin proteinleri değişik hızlarda yıkılır, bu nedenle makrofajların lipit y1kım ürünü içeriğinin tespit edilmesi, plak yaşının tespiti için iyi bir yöntem sağlar. CNPaz, MOG, MAG gibi küçük proteinler daha çabuk y1kıldıkları için bir-üç günlük erken aktif lezyonlar içinde bulunurken; PLP, MBP gibi büyük proteinler 10 güne kadar sebat edebilirler ve geç aktif lezyonların içinde de tespit edilirler. Inaktif plaklarda ise PAS veya oilred-O pozitif nötral lipid parçacıkları bulunur (7).

\subsection{Plak çeșitleri}

Bir MS hastasına MRG çekildiğinde T2 veya FLAIR'da hiperintens, T1'de ise izo- veya hipointens görünen çok sayıda plak görülür. Makroskopik olarak aktif plaklar yumuşak, sinırları belirsiz ve pembe renkli, kronik plaklar ise keskin sinırlı, sert ve gri renkli görünür (7). Görünürde birbirine benzeseler de bu plaklar aynı kişide ve/veya kişiler arası çok farklı histopatolojik özellikler gösterebilir (8). Lezyon yükü çok fazla görünen bir kişinin klinik durumu çok iyi iken, az sayıda lezyonu olan birinin kliniğinin çok daha ağır olabilmesinin temel sebebi budur.

Plakların sinıflandırılması temel olarak plağın aktif olup olmadığına, yaşına ve miyelinizasyon durumuna göre yapilır $(7,9)$. Buna göre akut aktif plaklar lipid içeren makrofajlar tarafindan yaygın olarak infiltre edilmiş (makrofaj denizi de denir), demiyelinize, aksonların görece korunduğu, yoğun perivasküler ve parenkimal $\mathrm{T}$ hücre ve bir miktar B hücre infiltrasyonunun eşlik ettiği, değişik oranlarda oligodendrosit hasarının görüldüğ̈u plaklardır. Plak merkezinde oligodendrosit prekürsörlerinin eşlik ettiği erken remiyelinizasyon alanları da s1klıkla eşlik eder. Belirgin reaktif astrositoz tipiktir ve neoplazmlarla karışttrrlabilir. Aksonlar görece korunsa da şişlikler, $\beta$-amiloid öncül proteininin 
birikimi ve hasarlanmalar eșlik edebilir. Aksonal hasar demiyelinizasyon kadar belirgin ise daha çok iskemik hastalıklar düşünülmelidir (7). Aktif plakların histopatolojik olarak dört farklı patern gösterdiğinden bahsedilmişti (2). Bir sonraki bölümde bu konuya ayrıntılarıyla değinilecektir.

Kronik aktif plaklar sınırları belirgin, myelin içeren makrofajların yoğun olarak plak sınırlarında görüldüğü, merkezi ise hiposelüler, gliotik ve inaktif görünen plaklardır. Sönmekte olan (smoldering) plaklar ise plak çeperlerinde az sayıda myelin içeren makrofaj bulunan, kronik plaklardır. Inaktif plaklar çok az sayida hücre içeren, demiyelinize, önemli miktarda akson ve oligodendrosit kaybının eşlik ettiği, gliotik plaklardır. Gölge plaklar ise remiyelinize olmuş keskin sınırlı plaklardır ve sayıları iyi klinik gidişle ilişskilidir (7).

Normal görülen beyaz cevherin incelendiği bir çalışmada, demiyelinizasyon görülmeksizin aktive mikroglial hücre öbeklerinin görüldüğü alanlar tespit edilmiş ve bunlara preaktif plaklar ad1 verilmiştir (10).

Akut ve kronik aktif plaklar relapsların halen görüldüğü hastalarda daha s1k görülürken, sönmekte olan ve gölge plaklar daha çok primer ve sekonder progresif MS hastalarında görülmektedir (7).

\subsection{Aktif plak paternleri}

Multiple Skleroz nasıl başlar? Beynin içinden kaynaklanan bir hastalık mıdır yoksa diş etkenlerin tetiklemesiyle beyne karşı gelişen immünolojik bir reaksiyon mudur? Dejeneratif süreçler mi ön plandadır yoksa inflamatuar süreçler mi? Tek bir hastalık midır yoksa heterojen bir grup hastalık m1dir? Bütün bu temel sorular MS camiasında halen tartışılmaktadır ve her bir cephesi saygin bilim insanlarınca oluşturulan gruplar arasinda fikir ayr1liklarına sebep olmaktadır.

\subsubsection{Dört patern hipotezi}

Daha önce bahsedildiği gibi, 2000 yilında Lucchinetti ve arkadaşları (2) tarafından yayınlanan 49 biyopsi, 32 otopsi vakası üzerinde yapılmış olan detaylı immünohistokimyasal (IHK) incelemelerle dayalı çalışma büyük yankı uyandırmıştır. Bu çalışmada incelenen bütün plakların dört immünopaternden birine ait olduğu ve bir insanda yalnız bir çeşit immünopatern görülebildiği bildirilmiştir. Buna göre hastalığın patogenezinin kişilerarası heterojenite gösterdiği iddia edilmiştir $(2,11)$.

Dört paternde de yoğun makrofaj ve lenfosit infiltrasyonu ortak nokta olmakla birlikte kompleman ve immünglobulin varlığ1 ve oligodendrosit apoptozu olup olmamas1 paternlerin birbirinden ayrilmasinda kistas olarak kullanılmıştır. İnflamasyonun ne kadar yoğun olduğu milimetreküpteki ortalama hücre sayılarından net olarak anlaşılabilir. Buna göre bir akut aktif bir plak içinde milimetreküpte yaklaş1k 1000 adet makrofaj, 100-150 adet T hücre, 5 adet plazma hücre bulunmaktadır. Oligodendrosit sayısı $\mathrm{Pa}$ tern I ve II'de $250 / \mathrm{mm}^{3}$, Patern III ve IV'te $50 / \mathrm{mm}^{3}$ ' tür. Patern I ve II'de T hücre ve makrofaj aracilı mekanizmalar ön planda olup, Patern II'de I'den farklı olarak kompleman aracılı sistem ve immünglobulinler de bol miktarda tespit edilmektedir. Patern III'te plak çevresinde oligodendrosit apoptozu en önemli patoloji iken, immünglobulin, kompleman ve remiyelinizasyon görülmez. Patern IV'de ise oligodendrositler distrofiktir. Patern I ve II'ye uyan plaklar venüller etrafinda görülürken, Patern III ve IV daha çok damarlardan uzakta, parenkim içerisinde saptanmıştır. Patern III'te plak sinırları belirsizdir. Hatta baz1 plaklarda Balo-benzeri konsentrik demiyelinize/miyelinize alanlar görülmüştür. Yine Patern III'te makrofajlarca özgül olarak MAG proteinin yıkıldığı, diğer miyelin proteinlerinin ise korunduğu bildirilmiştir. Diğer paternlerde ise bütün miyelin proteinleri beraber y1k1lmaktadır. (2) Paternlerin görülme sıklığına gelince, Lucchinetti ve arkadaşlarına (2) göre Patern I MS hastalarının $\% 15$ 'inde, Patern II \%58'inde, Patern III \%26'sinda, Patern IV ise \%1'inde görülmektedir.

\subsubsection{Paternlerin evrimi hipotezi}

Patern III'ün ilginç bir özelliği, bu paternin hemen tamamen yalnız 1-2 aydır semptomları bulunan kişilerde sap- tanmış olmasıdır. Patern II ise bütün evrelerde benzer oranlarda saptanmiştır (2). Bu durum Patern III'ün hastalığın erken evrelerine özgü olabileceğini düşündürtmüştür. Özellikle Avustralyalı araştırmacı Barnett ve arkadaşlarının (5) 2004 yılında yayınlanan, beyin sap1 tutulumu nedeniyle atak başlangıcından 17 saat sonra ölmüş bir hastada ve yine erken evrede hayatını kaybeden diğer altı hastada yaptığ1 otopsi bulguları yeni bir hipotezin doğmasını sağlamıştır $(5,13)$. Bu hipoteze göre bir plağın oluşumu ilk olarak plak bölgesinde yaygin oligodendrosit apoptozu ile bașlar. Saatler içinde gerçekleşen bu ilk evrede (prefagositik evre) aktive mikroglialardan başka hücre görülmez, ayrıca henüz miyelin korunmuştur bu nedenle plak kolaylikla fark edilmeyebilir. Kompleman pozitifliği ile birlikte mikroglialar da aktive olur ve apoptotik oligodendrositleri fagosite eder. 1-2 gün içinde oligodendrositler ortadan kaybolur ve miyelin tabakaları dejenere olarak vakuollü bir görüm alır. Bu modele göre makrofajlar, T hücre ve diğer hücrelerin plağa yerleşmesi görece geç bir hadisedir ve dejenere olan miyelin tabakalarını makrofajlar tarafindan fagositozu hastalı belirtilerinin zirve yaptı̆g ikinci ve üçüncü günlerde gerçekleşir (fagositik evre). Plak merkezinde remiyelinizasyonun başlaması da bu dönemde olur. İlk olarak oligodendrosit öncül hücreleri görülmeye başlar ve bir-iki hafta içerisinde matür oligodendrositler haline gelirler. $\mathrm{Bu}$ nedenle T-lenfositleri ve makrofajların bu ilk evrede zarar verici olmaktan çok iyileştirici etki sağladığ1 düşünülmektedir. Bu hipoteze göre oligodendrosit apoptozunu neyin başlattığ1 bilinmemektedir ve virüsler, hipoksik hasar, mikrogliadan salınan sitokinler sorumlu olabilir.

Bu plak modeli Lucchinetti ve arkadaşlarının (2) tarif etmiş olduğu Patern III'e benzese de kompleman aktivasyonunun görülmesi ve remiyelinizasyonun eşlik etmesi gibi temel farklllıklar göstermektedir. En önemli fark ise bu modelin ayrı bir patern değil özellikle hastalığın ilk yıllarında tüm plakların başlangıcını temsil eden temel bir mekanizma olabileceğini önerme-sidir $(14,15)$. Multiple Skleroz patogenezinde miyeline karşı otoreaktivite göste- 
ren T-lenfositlerin sistemik bir sebeple hasarlanan kan-beyin-bariyerini (KBB) geçerek dokuya yerleştikleri ve orada makrofajları aktive ederek miyelin ve doku hasarına yol açtıkları, hastalığın bu şekilde oluştuğu şeklinde yaygın bir görüş vardır. Prineas ve arkadaşlarına göre Barnett (5) miyelin hasarını başlatan olay beyin dişından değil beynin içinden gelir. Yani oligodendrositler bir sebeple apoptoza giderler ve oluşan miyelin parçacıklarını temizlemek için doğal bağışıklığın bir sonucu olarak (T-lenfosit aracılı adaptif bağıșıklığın değil) makrofajlar dokuda birikir ve miyelin fagositozunu başlatırlar. T ve $B$ lenfositlerin dokuda birikmesi makrofajlardan sonra gerçekleşir. Prineas grubu bu hipoteze destek olarak Patern II ve III özelliklerini taşıyan plakların aynı kişide görülebildiği şeklindeki gözlemlerini sunmaktadır (5).

2009'da aynı grup ikinci bir çalışma yayınlayarak bu modeli daha ayrintilı hale getirmiştir $(16,17)$. Buna göre yeni oluşmakta olan bir plak üç k1simdan oluşur: Prefagositik alan, fagositik alan ve postfagositik alan. En dişta yer alan prefagositik bölgede yalnız aktive mikroglialar bulunur, oligodendrositler apoptotik görünümdedir ve sayıları çok azalmıştır ya da hiç görünmeyebilirler. Myelin ise hafif soluk görünmekle birlikte büyük oranda korunmuştur. Takip eden fagositik alanda ise yoğun miyelin fagosite edici makrofaj infiltrasyonu, kompleman ve immunglobulin boyanması görülmektedir. T ve B lenfosit sayıs ise belirgin olarak azdır. Postfagositik alanda ise oil-red-O pozitif lipid y1kım ürünleriyle dolu makrofajlar ve diğer bölgelerden on kat fazla sayıda $T$ lenfositler görülmektedir. Perivasküler kilıflar da bu bölgelerde diğer bölgelere kıyasla çok daha kalabalık görünümde olup 400 hücreye kadar çıabilmekte ve değişen oranlarda CD4 ve CD8 T lenfositler, $\mathrm{B}$ lenfositler ve plazma hücrelerinden oluşmaktadırlar. Antijen sunan hücre (ASH) olarak MHC-II pozitifliği gösteren lenfositler, makrofajlar ve dendritik hücreler bu alanlarda gösterilmiştir (16).
$\mathrm{Bu}$ bulguların otopsi/biyopsi materyallerinde çok nadiren görülmesi bu hipotezin diğer gruplarca eleştirilmesine yol açmakla birlikte diğer çalışmaların çoğunun ileri evrelerdeki hastalarda yapiliyor olması nedeniyle bu hipotez de dört patern hipotezi gibi doğrulanmay1 beklemektedir. Lucchinetti ve arkadaşları (2) yakın zamanda yukarıdaki hipoteze karşı delil olarak nöromiyelitis optika (NMO) hastalarında yaptıkları otopsi çalışmasını öne sürmüşlerdir. Bu çalışma ile, başlangıç evresindeyken ölen NMO hastalarında, Barnett ve arkadaşlarının (5) 2004'te yayınladikları 17 saatlik indeks vakada saptanan bulgularla çok benzer histopatolojik bulgular saptadıklarını bildirmişler ve Prineas grubunun vakalarının klinik olarak da NMO ile uyumlu olduğunu ileri sürerek bu vakaların aslında MS değil NMO hastası olabileceğini iddia etmişledir (18). 2014'te yayınladıkları yeni çalışmada ise farklı 2 zamanda biyopsi yapılmış MS hastalarında, her iki biyopside de aynı paternin görülmeye devam ettiğini bildirmişlerdir. $\mathrm{Bu}$ bulgunun, farklı hastalarda farklı paternlerin görülebildiği, ancak aynı hastada hep aynı paternin görüldüğü hipotezini desteklediğini iddia etmişlerdir (19). Bağımsız grupların hem erken hem de ileri evre hastalarda yapacakları histopatolojik çalışmalar konunun aydınlatılmasına katkı sağlayacaktır.

\subsection{3 ileri evrelerde plak paternleri}

Yukarıda bahsedilen iki grubun çalışmaları en fazla birkaç yıldır hastalık belirtileri gösteren kişiler üzerinde yapılmıştı. Hollandalı bir grup ise uzun süredir hasta olan bir grubu (ortalama 22,2 y1ldir hasta olan 39 otopsi vakasi) incelemiş kişilerarası heterojenitenin bu grupta da var olup olmadığı sorusuna cevap aramıştır. Çalışmanın sonunda tüm hastalarda ve tüm plaklarda tek bir immünopatern saptanmıştır. $\mathrm{Pa}-$ tern II ile uyumlu olan bu patern d1şında çok nadiren apoptotik oligodendrositler saptanmıştır. Makrofajların siklıkla kompleman ve immunglobulinlerle kolokalizasyon gösterdiği saptanmış, miyelin fagositozunun opsonizasyon ve kompleman aktivasyonunu takiben hızla gerçekleştiği tespit edilmiştir. Bu bulgular hastalığın erken evrelerindeki patojenik heterojenitenin (ister kişilerarası ister aynı kişide farklı evrelerde olsun) ilerleyen evrelerde tek bir patogenetik tipe evrimleştiği şeklinde yorumlanmıştır $(6,20)$.

Uzun süredir hasta olan bireylerde remiyelinize olmuş gölge plakların da az görüldüğü bilinmektedir. 2002'de yayınlanmış bir çalışma bu durumun sebebini araştırmış, sonuçta plaklarda miyelinizasyon kapasitesi olan oligodendrosit hücrelerin bulunmasina rağmen remiyelinizasyonun gerçekleşemediğini saptamıştır. Bu durumun sebebi olarak, uygun hücreler bulunmasına rağmen aksonların fazla hasarlanmış olmaları nedeniyle miyelinizasyon için gereken sinyalin oluşamadığ1 ve remiyelinizasyonun gerçekleşmediği fikri öne sürülmüştür (21).

\subsection{Gölge plaklar}

Kara deliklerin aksine gölge plaklar olumlu bir parametreyi, remiyelinizasyonu göstermektedir. Remiyelinizasyon henüz akut plak evresinde oligodendrosit öncüllerinin demiyelinize olmuş çekirdek bölgesinde belirmesiyle ve olgunlaşarak miyelinizasyon kapasitesi kazanmasıyla başlamaktadır. Kronik plaklarda dahi bu öncül hücreler tespit edilmiş, ancak remiyelinizasyon gözlenmemiştir. Bunun sebebi olarak kronik plaklarda aksonların ileri derecede hasarlanmış olması ve oligodendrosit öncül hücrelerine gerekli sinyali ve trofik desteği verememeleri öne sürülmüştür (21).

Gölge plakların sayısı yaşam süresiyle pozitif korelasyon göstermektedir. Ancak hastalar arasında gölge plak oranlar1 yani remiyelinizasyon kapasiteleri belirgin farklilik göstermektedir. Radyolojik olarak gösterilebilmeleri zordur. Histopatolojik çalışmalarda 51 vakalık bir seride 10 vakada \%60-96, 34 vakada \%0-25 remiyelinizasyon saptanmıştır (22). Bu plaklar erken aktif dönemde seyrek görülürler. RRMS ve PPMS'te, SPMS'e göre daha s1k görülürler. Bazı gölge plaklarda (SPMS'te daha sık olarak) sınır bölgelerde reaktivasyon, aktif demiyelinizasyon ve plak büyümesi görülebilir (23). 


\subsection{Kortikal plaklar}

Kortikal ve spinal kord atrofisi hastalık ciddiyetiyle en iyi korelasyon gösteren parametredir (24). Kortikal atrofi sekonder progresif evrede hız kazanır (25). Son y1llardaki çalışmalar, sekonder progresif evredeki yavaş-progresif seyrin kortikal gri cevher hasarına bağlı olduğunu düşündürtmektedir (9).

Bununla birlikte günlük pratiğimizde kullandığımız MRG cihazları ve teknikleri kortikal lezyonları göstermede yetersiz kaldıkları için ileri evrelerde kortikal atrofi belirginleşene kadar korteksin etkilenmediği ya da az etkilendiği yanılsamasına kapılırız. Hâlbuki yüksek çözünürlüklü MRG cihazlarının ve non-konvansiyonel MRG tekniklerinin gelişmesi sayesinde klinik izole sendrom evresinde bile \%30-40 hastada beyaz cevher lezyonlarıyla birlikte kortikal plakların ve inflamasyonun gelişmekte olduğunu artık biliyoruz $(26,27)$. Ayrıca bulgular, kortikal patolojinin beyaz cevher patolojisinden bağımsız ilerlediğini ve hatta kimi hastalarda baskin patoloji olabildiğini göstermektedir (28). Kortikal lezyonların birikimi RRMS'ten SPMS'e geçişte önemli rol oynar (29). Bu lezyonlar singulat gi-

\section{KAYNAKLAR}

1. Clanet M. Jean-Martin Charcot. 1825 to 1893. Int MS J 2008;15:59-61.

2. Lucchinetti C, Bruck W, Parisi J, Scheithauer B, Rodriguez M, Lassmann H. Heterogeneity of multiple sclerosis lesions: implications for the pathogenesis of demyelination. Ann Neurol 2000;47:707-717.

3. De Groot CJ, Bergers E, Kamphorst W, et al. Post-mortem MRI-guided sampling of multiple sclerosis brain lesions: increased yield of active demyelinating and (p)reactive lesions. Brain 2001;124:1635-1645.

4. Bo L, Geurts JJ, Ravid R, Barkhof F. Magnetic resonance imaging as a tool to examine the neuropathology of multiple sclerosis. Neuropathol Appl Neurobiol 2004;30:106-117.

5. Barnett MH, Prineas JW. Relapsing and remitting multiple sclerosis: pathology of the newly forming lesion. Ann Neurol 2004;55:458-468. rus, frontal ve temporal korteksler ve hippokampusta daha sık görülür. Primer motor korteks ve oksipital kortekste ise daha hafiftir. Ayrica talamus, bazal ganglia, hipotalamus, serebellum ve spinal kord grimaddesinde de görülebilir (9).

Kortikal lezyonlar son yıllardaki histopatolojik çalışmalarla ayrıntılı bir şekilde tarif edilmeye başlanmıştır. Buna göre topografik olarak üç çeşit kortikal plak bulunmaktadır: Subpial, lökokortikal ve intrakortikal ${ }^{26}$. Lökokortikal plaklar $\% 50$ oranında görünürken, subpial plaklar \%34, intrakortikal plaklar \%17 oranında görülür. Kortikal plaklar beyaz cevher plaklarından farklı inflamasyon özellikleri gösterir. Özellikle ileri evrede kortekste inflamatuar hücre çok az sayıda bulunur. Erken evrede ise kortikal plakların yaklaş1k \%80'inde T-hücre infiltrasyonu, \%40'ında makrofaj infiltrasyonu saptanmıştır. Bununla birlikte KBB geçirgenliği artmaz, kompleman aktivasyonu yoktur ve mikroglia aktivasyonu daha belirgindir. Özellikle 3 . ve 5. kortikal tabakalarda nöronal apoptoz belirgindir. Normal görünüşlü gri cevherde de nöron apoptozu görülebilir. Özellikle meningeal inflamasyonun yoğun olarak gözlendiği

6. Breij EC, Brink BP, Veerhuis R, et al. Homogeneity of active demyelinating lesions in established multiple sclerosis. Ann Neurol 2008;63:16-25.

7. Popescu BF, Lucchinetti CF. Pathology of demyelinating diseases. Annu Rev Pathol 2012;7:185-217.

8. Frohman EM, Racke MK, Raine CS. Multiple sclerosis--the plaque and its pathogenesis. N Engl J Med 2006;354:942-955.

9. Reynolds R, Roncaroli F, Nicholas R, Radotra B, Gveric D, Howell O. The neuropathological basis of clinical progression in multiple sclerosis. Acta Neuropathol 2011;122:155-170.

10. van der Valk P, Amor S. Preactive lesions in multiple sclerosis. Curr Opin Neurol 2009;22:207-213. alanların yaklaşık \%90'inda subpial plakların eşlik ettiği bilinmektedir. Bu durum inflamatuar sitokinlerin difüzyonunun kortikal plakların patogenezinde rol oynadığını düşündürtmektedir $(9,26)$.

İlerleyen evrelerde, özellikle sekonder progresif MS'te yaygin meningeal inflamasyonun ve kortikal lezyonların yükü artmaktadır. Hatta sulkusların derine indiği korunaklı bölgelerde ektopik lenf folliküllerini andiran Bhücre agregatlarının oluştuğu da tespit edilmiştir. Bu agregatların oligoklonal bant pozitifliğine ve yüksek immunglobulin indeksine katkıda bulunuyor olabilecekleri düşünülmektedir. Meningeal inflamasyon ne kadar fazla ise subpial plaklar ve kortikal demiyelinizasyon ve atrofi de o kadar fazla olmaktadır (30).

Sonuç olarak, MR görüntülerinde daha çok dikkat çeken aksonal hasar ve inflamasyon yükü dizabiliteye katkıda bulunsa da özellikle sekonder progresif evredeki yavaş seyirli ilerleyişi açıklamada yetersiz kalmaktadır. Kortikal gri cevher hasarının bu seyirde temel rol oynadığ bilinmelidir.

11. Ludwin SK. Understanding multiple sclerosis: lessons from pathology. Ann Neurol 2000;47:691-693.

12. Lucchinetti CF, Bruck W, Lassmann H. Evidence for pathogenic heterogeneity in multiple sclerosis. Ann Neurol 2004;56:308.

13. Pender MP. Oligodendrocyte apoptosis before immune attack in multiple sclerosis? Ann Neurol 2005;57:158; author reply 158-159.

14. Barnett MH, Henderson AP, Prineas JW. The macrophage in MS: just a scavenger after all? Pathology and pathogenesis of the acute MS lesion. Mult Scler 2006;12:121-132.

15. Barnett MH, Parratt JD, Pollard JD, Prineas JW. MS: is it one disease? Int MS J 2009;16:57-65. 
16. Henderson AP, Barnett MH, Parratt JD, Prineas JW. Multiple sclerosis: distribution of inflammatory cells in newly forming lesions. Ann Neurol 2009;66:739-753.

17. Tsutsui S, Stys PK. Degeneration versus autoimmunity in multiple sclerosis. Ann Neurol 2009;66:711-713.

18. Bruck W, Popescu B, Lucchinetti CF, et al. Neuromyelitis optica lesions may inform multiple sclerosis heterogeneity debate. Ann Neurol 2012;72:385-394.

19. Metz I, Weigand SD, Popescu BF, et al. Pathologic heterogeneity persists in early active multiple sclerosis lesions. Ann Neurol 2014;75:728-738.

20. Raine CS. Multiple sclerosis: classification revisited reveals homogeneity and recapitulation. Ann Neurol 2008;63:1-3.

21. Chang A, Tourtellotte WW, Rudick R, Trapp BD. Premyelinating oligodendrocytes in chronic lesions of multiple sclerosis. $\mathrm{N}$ Engl J Med 2002;346:165-173.

22. Patrikios P, Stadelmann C, Kutzelnigg A, et al. Remyelination is extensive in a subset of multiple sclerosis patients. Brain 2006;129:3165-3172.

23. Bramow S, Frischer JM, Lassmann H, et al. Demyelination versus remyelination in progressive multiple sclerosis. Brain 2010;133:2983-2998.

24. Bonati U, Fisniku LK, Altmann DR, et al. Cervical cord and brain grey matter atrophy independently associate with long-term MS disability. J Neurol Neurosurg Psychiatry 2011;82:471-472.

25. Fisniku LK, Chard DT, Jackson JS, et al. Gray matter atrophy is related to longterm disability in multiple sclerosis. Ann Neurol 2008;64:247-254.

26. Lucchinetti CF, Popescu BF, Bunyan RF, et al. Inflammatory cortical demyelination in early multiple sclerosis. N Engl J Med 2011;365:2188-2197.

27. Calabresi PA. Inflammation in multiple sclerosis--sorting out the gray matter. N Engl J Med 2011;365:2231-2233.

28. Calabrese M, Filippi M, Gallo P. Cortical lesions in multiple sclerosis. Nat Rev Neurol 2010;6:438-444.

29. Stadelmann C. Multiple sclerosis as a neurodegenerative disease: pathology, mechanisms and therapeutic implications. Curr Opin Neurol 2011;24:224-229.

30. Magliozzi R, Howell O, Vora A, et al. Meningeal B-cell follicles in secondary progressive multiple sclerosis associate with early onset of disease and severe cortical pathology. Brain 2007;130:10891104. 